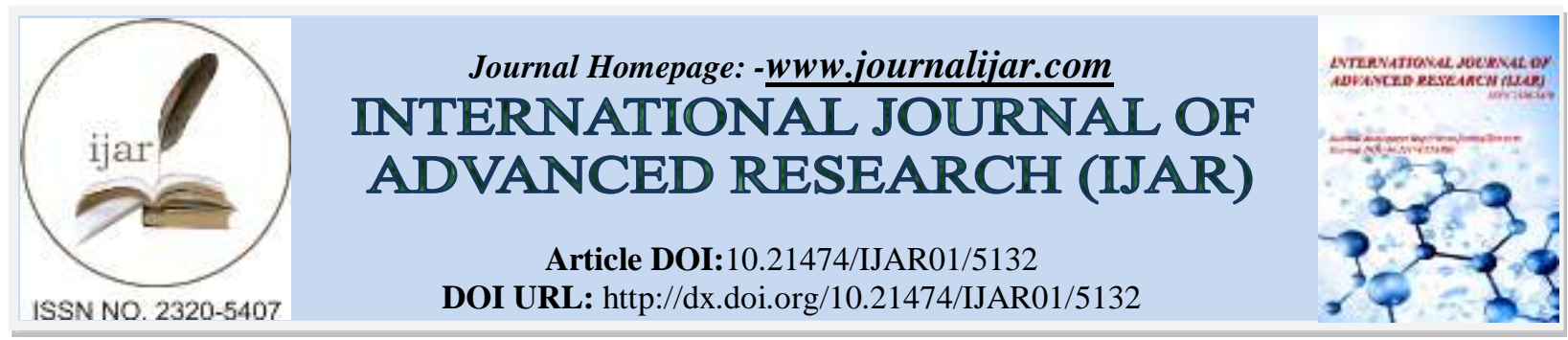

RESEARCH ARTICLE

\title{
INDUCTION OF APOPTOSIS BY THE ETHYL ACETATE FRACTION OF WOODFORDIA FRUTICOSA KURZ. FLOWERS THROUGH NFKB MEDIATION IN HEPATOCELLULAR CARCINOMA.
}

\author{
N. R Raji, P Roshni and "M. S Latha. \\ *Professor, Pharmacognosy Laboratory, School of Biosciences, Mahatma Gandhi University, Kottayam (Dist), \\ Kerala -686560 .
}

\section{Manuscript Info}

Manuscript History

Received: 10 June 2017

Final Accepted: 12 July 2017

Published: August 2017

Key words:-

Woodfordiafruticosa, HepG2, NF-кB, p53, p21, GAPDH

\begin{abstract}
Cancer is a disease that has made mankind distraught for the development of efficient strategies in curbing the onset, spread and mortality related to the disease. As synthetic chemotherapeutics add more complexities to the efficacy in treating cancer, plant related drug development has proven to be both an efficient and pharmaceutically favoured alternative to the same. Woodfordia fruticosa Kurz is a traditionally hailed medicinal plant. Research conducted upon the flowers of the plant has attributed hepatoprotective, antioxidant, anticancer and anti-inflammatory properties to its alcoholic extracts.

The objective of the present study was to fractionate the most active alcoholic extract, analyse the phytoconstituents of the various fractions and to evaluate the anticancer efficacy and apoptosis induction potential of the most active fraction on hepatocellular carcinoma cell lines.

Our study revealed that the ethyl acetate fraction of the methanolic extract of Woodfordia fruticosa flowers were rich in polyphenols such as flavonoids, tannins and terpenoids. The fraction showed profound cytotoxicity upon HepG2 cell when analysed using MTT assay. Induction of apoptosis was confirmed using Acridine Orange/Ethidium Bromide (AO/EtBr) double staining. The fraction efficiently downregulated the expression of Nuclear Factor Kappa B (NF- $\mathrm{KB}$ ) and upregulated the expression of tumor suppressor gene p53 and cell cycle regulatory gene p21 when compared to the expression of Glyceraldehyde -3- Phosphate dehydrogenase (GAPDH) gene taken as control. Our study proved that the ethyl acetate fraction of the plant could be an active source of polyphenolics compounds with potent anticancer activity.
\end{abstract}

Copy Right, IJAR, 2017, All rights reserved.

\section{Introduction:-}

Cancer, a multifactorial disease has been held responsible for more than $13 \%$ of the deaths in the global scenario (Padma, 2015). Though a large number of strategies to curbing the onset, development and spread of the disease has been brought in practice, majority of the treatment administered to patients rely upon chemotherapeutic agents. However, the low therapeutic index, lack of specificity, both in action and distribution in the body after intravenous administration etc lead to a large number of side effects that eventually affect healthy tissues (Ismael et. al., 2008). 
As an alternative, plant based drugs and active compounds of therapeutic value of plant origins are being constantly evaluated for their anti-cancer activities. Such compounds together with novel methods of in-situ drug delivery systems may hold the key to an effective medicinal cure for cancer sans the fear for side effects.

The dysfunction of the apoptotic machinery in healthy cells transforms them to cancerous cells. The genes involved as well as the proteins produced in the various apoptotic pathways of cells are the most preferred targets for anticancer drug development (Wong., 2011). Misguided expression of many of these gene products are being effectively utilised as markers in detection and diagnosis of a number of cancers. Many plant derived compounds show profound effects on the cancer cells by targeting the moieties associated with the apoptotic pathway.

Traditional treatises on medicinal plants mention the use of Woodfordia fruticosa Kurz., commonly called the "fire flame bush' as a fermenter in the preparation of many Ayurvedic concoctions (Syed et. al., 2013). Researches conducted upon the plant have attributed antioxidant, hepatoprotective and anticancer properties among the many activities of the plant (Sharma, 2011; Chaturvedi et. al., 2012). Crude alcoholic extracts of the plant have been known to be a rich source of polyphenolics such as tannins and flavonoids and previous studies conducted upon the methanolic extracts attributed anticancer activities in in-vivo models (Nitha et. al., 2014). The present study aimed at the fractionation of the most active alcoholic (methanolic) extract of the plant and determination of their anticancer activities using cancer cell lines.

\section{Materials and Methods:-}

\subsection{Chemicals:-}

The chemicals used in this study are of analytical grade. Biochemical reagents used were purchased from Merck, India and all the apparatus used for tissue culture were procured from Tarsons, India.

\subsection{Collection of Plant material and Extraction}

Woodfordia fruticosa Kurz. flowers were obtained from the natural habitat during the months of NovemberJanuary. The plant was authenticated by Mr. Roji Thomas, C.M. S College, Kottayam and a voucher specimen (SBSBRL0021) was maintained at the institute. The flowers obtained were washed thoroughly, chopped, shade dried and powdered. $50 \mathrm{~g}$ of the powdered plant was extracted with $500 \mathrm{ml}$ of solvents of increasing polarity for 48 hrs each in a continuous manner. The methanolic extract obtained was concentrated using a rotary evaporator. The yield of the extract was $12 \%$.

\subsection{Fractionation}

Methanolic extract of Woodfordia fruticosa flowers were fractionated using the Kupchan's method (Suganya and Thangaraj, 2014). About $10 \mathrm{~g}$ of the crude extract was dissolved in $10 \mathrm{ml}$ methanol and taken in a separating funnel. The extract was separated using solvents of increasing polarity viz petroleum ether, chloroform, ethyl acetate and methanol. The fractions obtained were collected, dried and stored at room temperature.

\subsection{Phytochemical Analysis}

The various fractions obtained were subjected to preliminary phytochemical analysis for the determination of the presence of various phytochemicals such as alkaloids, flavonoids, tannins, terpenoids and saponins (Sasidharan et. al., 2011)

\subsection{Cultivation of Liver Cancer Cells}

Liver cancer cells (HepG2) were initially procured from NCCS, Pune and maintained in DMEM supplemented with $10 \%$ FBS, $2 \mathrm{mM}$ glutamine, sodium bicarbonate and antibiotic solution comprising of Penicillin $(100 \mathrm{U} / \mathrm{ml})$, Amphotericin B $(2.5 \mu \mathrm{g} / \mathrm{ml})$ and Streptomycin $(100 \mu \mathrm{g} / \mathrm{ml})$. The culture was maintained in a humid environment with $5 \% \mathrm{CO}_{2}$ at $37^{\circ} \mathrm{C}$ and sub-cultured three times a week depending on the confluency.

\section{Antiproliferative Activity of Woodfordia fruticosa fractions:-}

\subsubsection{Preparation of Plant Fractions}

$1 \mathrm{mg}$ of selected fraction of the plant extract was dissolved in $1 \mathrm{ml}$ of DMEM using a cyclomixer and filtered through a $0.22 \mu \mathrm{m}$ Millipore syringe filter. The fractions were serially diluted appropriately to obtain solutions of various concentrations i.e. $100 \mu \mathrm{g}, 50 \mu \mathrm{g}, 25 \mu \mathrm{g}, 12.5 \mu \mathrm{g}, 6.25 \mu \mathrm{g}$ in $100 \mu \mathrm{l}$ of DMEM. 


\subsubsection{Determination of Antiproliferative Activity}

Two days old confluent monolayer of cells were trypsinized and the cells were suspended in $10 \%$ growth medium, $100 \mu 1$ cell suspension $\left(5 \times 10^{4}\right.$ cells/well $)$ wasseeded in 96 well tissue culture plate and incubated at $37^{\circ} \mathrm{C}$ in a humidified 5\% $\mathrm{CO}_{2}$ incubator. After $24 \mathrm{hr}$ incubation of the cells in the 96 well plate, $100 \mu \mathrm{l}$ of the plant fractions in various concentrations were added to wells in triplicate and incubated. The cells were observed for morphological changes at regular intervals using an inverted phase contrast microscope.

\subsection{Cytotoxicity Assay}

The cytotoxic ability of the plant fractions was determined using MTT Assay. The assay relies upon the production of a measurable purple formazan product formed by the cleavage of (3-(4, 5-dimethyl thiazol-2yl) - 2, 5-diphenyl tetrazolium bromide (MTT) by mitochondrial enzymes of viable cells (Thakkar et. al., 2014). HepG2 cells were seeded onto a 96 well plate and incubated at standard condition along with different concentration of plant fractions as mentioned in the section above.

Fifteen mg of MTT was reconstituted in $3 \mathrm{ml}$ PBS until completely dissolved and sterilized by filter sterilization. After 24 hours of incubation period, the sample content in wells were removed and 30 1 of reconstituted MTT solution was added to all test and cell control wells and incubated at $37^{\circ} \mathrm{C}$ in a humidified $5 \% \mathrm{CO}_{2}$ incubator for 4 hours. After incubation, the supernatant was removed and $100 \mu 1$ DMSO was added to the wells and mixed to solubilize the formazan crystals. The absorbance values were measured by using microplate reader at a wavelength of $570 \mathrm{~nm}$. The percentage of growth inhibition was calculated using the formula:

$\%$ viability $=(\mathrm{OD}$ sample $/ \mathrm{OD}$ control $) \times 100$

\subsection{Determination of Apoptosis by Acridine Orange (AO)/ Ethidium Bromide (EtBr) Double Staining.}

$\mathrm{AO} / \mathrm{EtBr}$ Double staining is a vital assay for determining apoptosis and is based on differential uptake of both the dyes by cells. While AO enters both live and dead cells and produces green fluorescence, EtBr enters cells that have lost membrane integrity and produces a contrasting orange fluorescence (Ribble et. al., 2005). HepG2 cells were maintained along with selected concentration of the plant extract in a 12 well culture plate under standard conditions to form a monolayer.The cells were washed with cold PBS and stained with a mixture of AO $(100 \mu \mathrm{g} / \mathrm{ml})$ and EB $(100 \mu \mathrm{g} / \mathrm{ml})$ at room temperature for $10 \mathrm{~min}$. The stained cells were washed twice with 1X PBS and observed under fluorescence microscope.

\subsection{RT-PCR (Reverse Transcriptase - Polymerase Chain Reaction) Analysis}

Total RNA was prepared using Trizol based Total RNA isolation kit (Invitrogen, USA) according to the manufacturer's instructions.

The cDNA synthesis was performed using Thermo scientific verso cDNA Synthesis kit Pro. About $4 \mu 1$ of $5 \mathrm{X}$ cDNA synthesis buffer, $2 \mu 1$ ofdNTP mix, $1 \mu 1$ of anchored oligodT, $1 \mu 1$ of RT Enhancer, $1 \mu 1$ of Verso Enzyme Mix and 5 $\mu 1$ of RNA template (1ng of total RNA) were added to an RNAse free tube and the total reaction volume was made up to $20 \mu \mathrm{l}$ using sterile distilled water. The reaction was conducted in a thermal cycler (Eppendorf Master Cycler) using a reaction cycle at $42^{\circ} \mathrm{C}$ for 30 minutes followed by $92^{\circ} \mathrm{C}$ for 2 minutes.

The amplification was done using ThermoScientific amplification kit. $25 \mu \mathrm{L}$ of PCR Master Mix (2X), $2 \mu \mathrm{L}$ each of Forward primer $(0.1-1.0 \mu \mathrm{M})$ and Reverse primer $(0.1-1.0 \mu \mathrm{M})$ and $5 \mu \mathrm{L}$ of Template DNA (10 pg - $1 \mu \mathrm{g})$ were added to a reaction tube and the final volume was made upto $50 \mu \mathrm{L}$ with sterile distilled Water. The reaction cycle involved a Initial denaturation at $95^{\circ} \mathrm{C}$ for 3 minutes, followed by denaturation at $95^{\circ} \mathrm{C}$ for $30 \mathrm{~s}$, annealing at $55^{\circ} \mathrm{C}$ for $30 \mathrm{~s}$ and extension at $72^{\circ} \mathrm{C}$ for 1 minute, repeated for 35 cycles and a final extension was provided at $72^{\circ} \mathrm{C}$ for 5 minutes. After the amplification, the PCR products were visualised on $2.5 \%$ agarose gels using Ethidium bromide staining.

\section{Results:-}

\subsection{Phytochemical Analysis}

Phytochemical analysis conducted upon the fractions obtained from the methanolic extract of Woodfordia fruticosa Kurz. Flowers revealed that the ethyl acetate fraction were rich in polyphenolics, tannins and flavonoids. The methanolic fraction also showed a less eminent but positive presence of flavonoids and tannins. (Table 1) 


\subsection{Antiproliferative Activity of the Plant fraction}

Woodfordiafruticosa fractions altered the morphology of the HepG2 cells. At concentrations above $12.5 \mu \mathrm{g} / \mathrm{ml}$, distinct morphological changes were observed in the cells such as rounding or shrinking of cells, granulation and vacuolization in the cytoplasm of the cells and disintegration of cell nucleus which can be considered as symptoms of cytological damage pertaining to cell death/apoptosis. (Fig 1A-F)

\subsection{Cytotoxicity Assay}

The percentage of cell viability was calibrated using MTT assay. The ethyl acetate fraction showed profound cytotoxic activity upon HepG2 cells. The cells showed $60 \%, 55 \%, 44 \%$ and $39 \%$ viability at concentrations of $6.25 \mu \mathrm{g} / \mathrm{ml}, 25 \mu \mathrm{g} / \mathrm{ml}, 50 \mu \mathrm{g} / \mathrm{ml}$ and $100 \mu \mathrm{g} / \mathrm{ml}$ respectively (Fig 3). The LD50 of the fraction was calibrated as $36.339 \mu \mathrm{g} / \mathrm{ml}$.

\subsection{Determination of Apoptosis by Acridine Orange (AO)/ Ethidium Bromide (EtBr) Double Staining.} $\mathrm{AO} / \mathrm{EtBr}$ staining is an effective tool for the determination of apoptosis. Acridine Orange uptake occurs in both live and dead cells and is indicated by green fluorescence showed in the control while selective uptake of ethidium bromide occurs in non-viable cells and is indicated by red fluorescence. Treatment of HepG2 cells with the ethyl acetate fraction of Woodfordia fruticosa flowers showed an increase in red fluorescence thereby suggesting the induction of apoptosis/cell death. (Fig 2A-B).

\subsection{RT-PCR (Reverse Transcriptase - Polymerase Chain Reaction) Analysis}

Expression of the tumor suppressor gene p53, cell cycle regulator p21, Nuclear Factor kappa B (NFKB) and GAPDH were studied. Elevated expression levels of p53, p21 and depression in the levels of NFKB gene expression in treated cells when compared to the untreated cells confirmed the induction of apoptosis by the fraction. GAPDH gene was used as a control and the expression of GAPDH remained the almost the same in both treated and untreated cells. (Fig 4A-B).

\section{Discussion:-}

Plant secondary metabolites are a wide repository of compounds with profound therapeutic potential. Of the many varieties of compounds present in plants polyphenolics such as flavonoids and tannins are a major class. Woodfordia fruticosa flowers are a rich source of polyphenolics and some of the polyphenolics isolated from the crude extracts of the plant are Woodfordin, Oenothein, Ellagic acid etc (Kumar et. al.,2016). The attempt made in this study was to fractionate the alcoholic extract of the flowers and to determine a possible mechanism for its anticancer activity. The ethyl acetate fraction of the methanolic extract was found to contain polyphenolics such as flavonoids and terpenoids and the presence of these phytocompounds renders its anticancer activity.

Hepatocellular carcinoma cell line HepG2 was selected for this study. The morphology of the normal HepG2 cells is similar to epithelial cells (Wilkening et. al., 2003). Change in morphology of the cells such as rounding off of the edges, blebbing and loss of nuclear integrity, which can be compared to the classic symptoms of apoptosis (Su et. al., 2016), was observed when the cells were treated with the ethyl acetate fraction on a concentration dependent basis. Our findings validate that the plant fraction induces apoptosis in cancer cells. Cytotoxicity assay conducted on the cell line using the plant fraction also confirmed its apoptosis inducing activity.

Over expression of certain genes is a hallmark trait of cancer and phytocompounds with anticancer activity compels variation in the expression of genes when cells are culture in their presence. This study focused on some key genes expressed by HepG2 cells and the influences of the plant fraction upon these genes were studied using the GAPDH gene as the control. GAPDH or Glyceraldehyde -3- Phosphate dehydrogenase is an enzyme involved in the glycolytic pathway. GAPDH is considered as a 'house-keeping gene'; which is expressed in an unparallel way in both tumour and normal cells (Said et. al., 2009). In our study, the expression of GAPDH remained almost similar in both untreated and treated cells thereby justifying the role of GAPDH in expression studies as a control.

Nuclear Factor kappa B (NF- $\mathrm{KB}$ ) refers to a family of transcription factors involved in the pathways of apoptosis and inflammation. Appropriate stimulus triggers the activation of these factors in normal cells and on completion of transcription of the target genes, these factors return to their inactive states in normal cells. Tumour cells elicit a damaged regulation of these factors which result in progression of tumours due to lack of cell death (Pajaniradje et. al., 2014). Woodfordia fruticosa fractions showed a downregulation of NF- $\mathrm{BB}$ in treated cells, indicating the apoptotic activity of the plant through NF-kB mediation. 
The tumour suppressor gene product, p53 is aptly termed 'the guardian of the genome' owing to its influence in DNA damage repair, growth arrest and most importantly apoptosis. p53 gene is known to influence p21 waf-1, an inhibitor of cell cycle progression (Reaves et. al., 2000). Hepatoblastoma derived HepG2 cell line is unique in expressing a wild form of p53 which can be activated to elicit normal p53 functioning under conditions of stress such as induced hypoxia. Upregulation of p53 was observed in HepG2 cells treated with Woodfordia fruticosa fraction suggesting that the plant phytocompounds elicit apoptosis induction through p53 regulation. Since p53 expression influences p21, increased expression of p21 expression observed in our study clearly indicate the induction of apoptosis via p53-p21 mediated pathway by the plant fraction.

The present study evaluated the capability of the ethyl acetate fraction of Woodfordia fruticosa methanolic extract to induce natural cell death in a tumour cell line bringing about a possible mechanism of its activity. A probe into the active constituents present in the fraction could reveal the phytocompounds that are responsible for its remarkable effect, thereby revealing new targets for designing new anticancer drugs.

\section{Conclusion:-}

Summarising, earlier studies conducted at our laboratory proved that the methanolic extract of Woodfordia fruticosa had potent anticancer activity. The methanolic extract was subjected to fractionation following which qualitative estimation of phytochemicals was conducted on the fractions. Ethyl acetate fraction of the methanolic extract was found to contain tannins, terpenoids and flavonoids and was selected for further studies on HepG2 cell lines. Cytotoxicity assays confirmed the apoptosis inducing potential of the fraction and gene expression studies conducted on the fraction treated HepG2 cells revealed that the expression patterns of apoptosis related genes such as $\mathrm{NF \kappa B}$, p53 and p21 were efficiently altered. This study indicates to the need of further determination of constituent phytochemicals in the selected fraction of Woodfordia fruticosa which may serve as potential leads to an effective apoptosis inducer drug for cancer therapy.

\section{Conflict Of Interest:-}

The authors declare that they have no competing interests.

\section{Acknowledgement:-}

The financial support received from Kerala State Council for Science Technology and Environment (KSCSTE ) Science Research Scheme (No.026/SRSLS/2014/CSTE) is gratefully acknowledged by the authors.

\section{Results:-}

\begin{tabular}{|l|l|l|l|l|}
\hline Phytochemical & $\begin{array}{l}\text { Petroleum Ether } \\
\text { Fraction }\end{array}$ & Chloroform Fraction & $\begin{array}{l}\text { Ethyl Acetate } \\
\text { Fraction }\end{array}$ & Methanol Fraction \\
\hline Alkaloid & - & + & - & - \\
\hline Flavonoid & - & + & ++ & +++ \\
\hline Terpenoid & - & - & +++ & + \\
\hline Tannin & - & - & - & + \\
\hline Saponin & - & - & - & - \\
\hline Fats & + & - & & \\
\hline
\end{tabular}

Table 1:-Phytochemical Analysis of the various fractions of the methanolic extract of Woodfordia fruticosa Kurz. Flowers. (+ mild positive, ++ positive, +++ highly positive, - negative) 

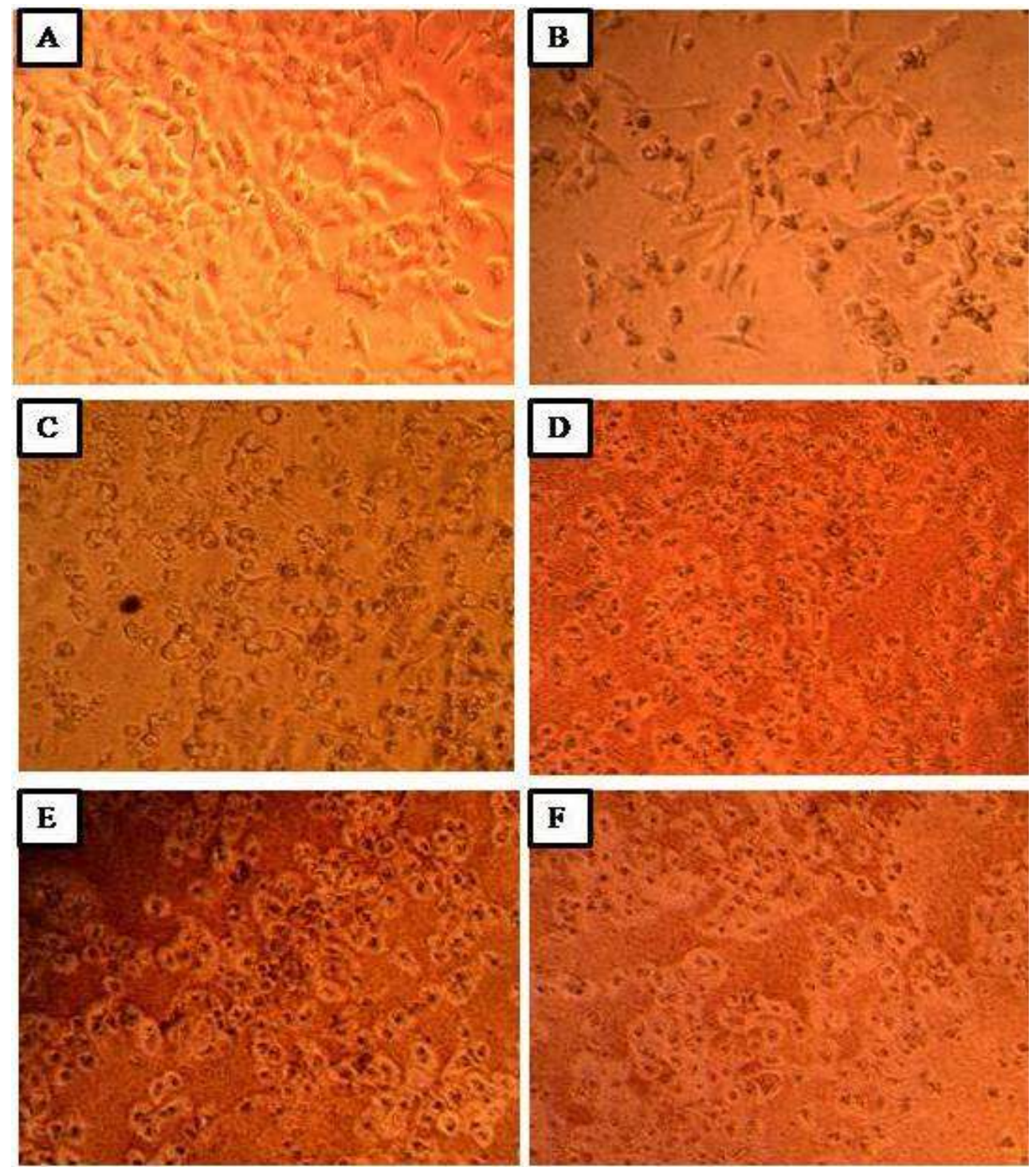

Figure 1:-Antiproliferative Activity of the Ethyl acetate fraction of Woodfordia fruticosa methanolic extract. A - Normal Control.

B-F - Cells treated with $6.5 \mu \mathrm{g} / \mathrm{ml}, 12.5 \mu \mathrm{g} / \mathrm{ml}, 25 \mu \mathrm{g} / \mathrm{ml}, 50 \mu \mathrm{g} / \mathrm{ml}$ and $100 \mu \mathrm{g} / \mathrm{ml}$ of plant fraction
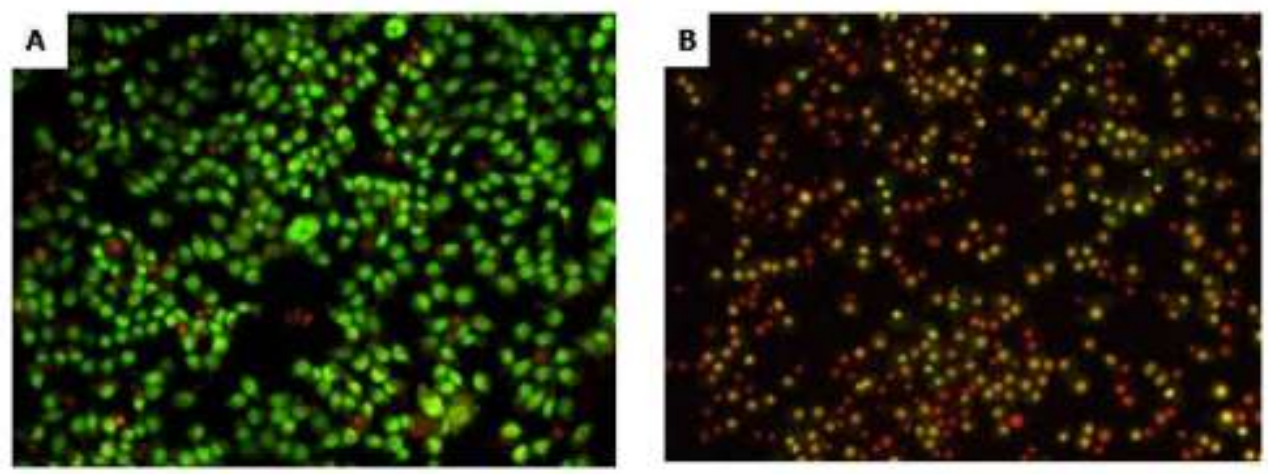

Figure 2:-Acridine Orange/Ethidium Bromide Double Staining

A: Live and Dead Cells Uptake Acridine Orange, Emits Green Flourescence

B: Dead/ Non-viable cells take up Ethidium Bromide, Emits Red Flourescence 


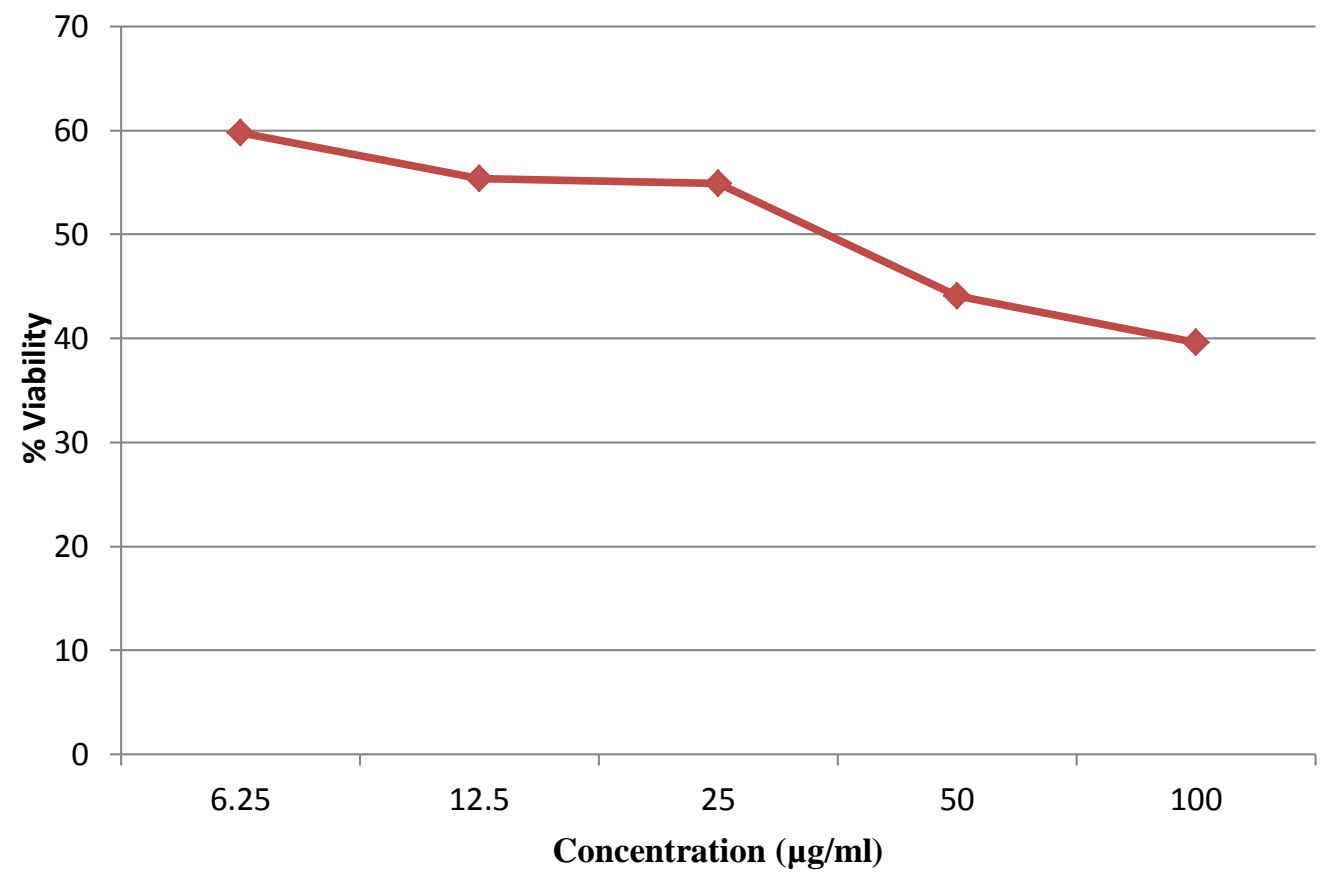

Figure 3:- Cytotoxicity Assay of Woodfordia fruticosa fraction

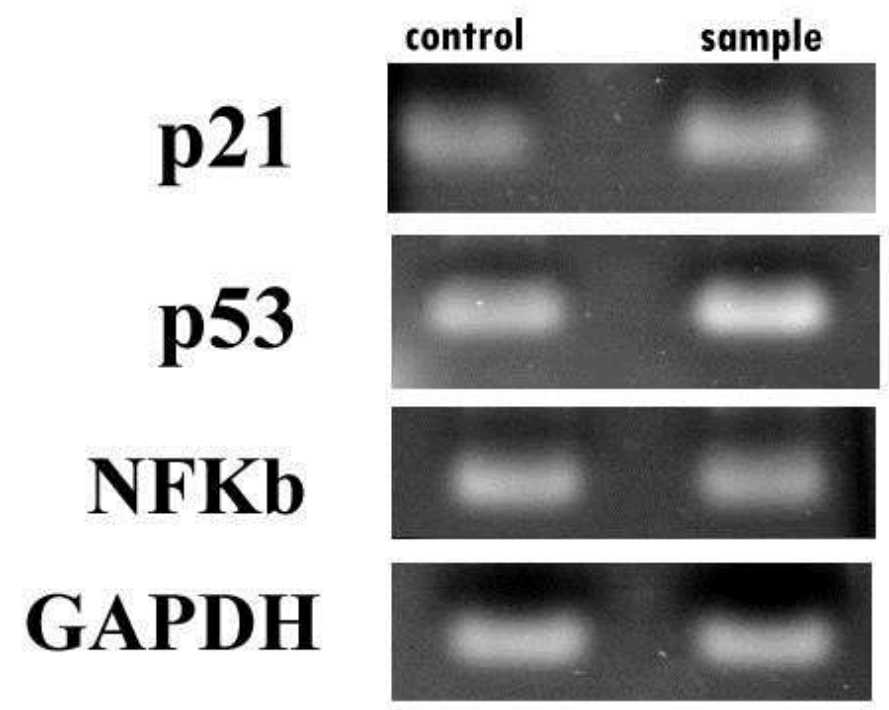

Figure 4 A:-Expression studies conducted on HepG2 cells. Agarose Gel Electrophoresis of Gene Expression Pattern in Untreated and Treated HepG2 cells. 


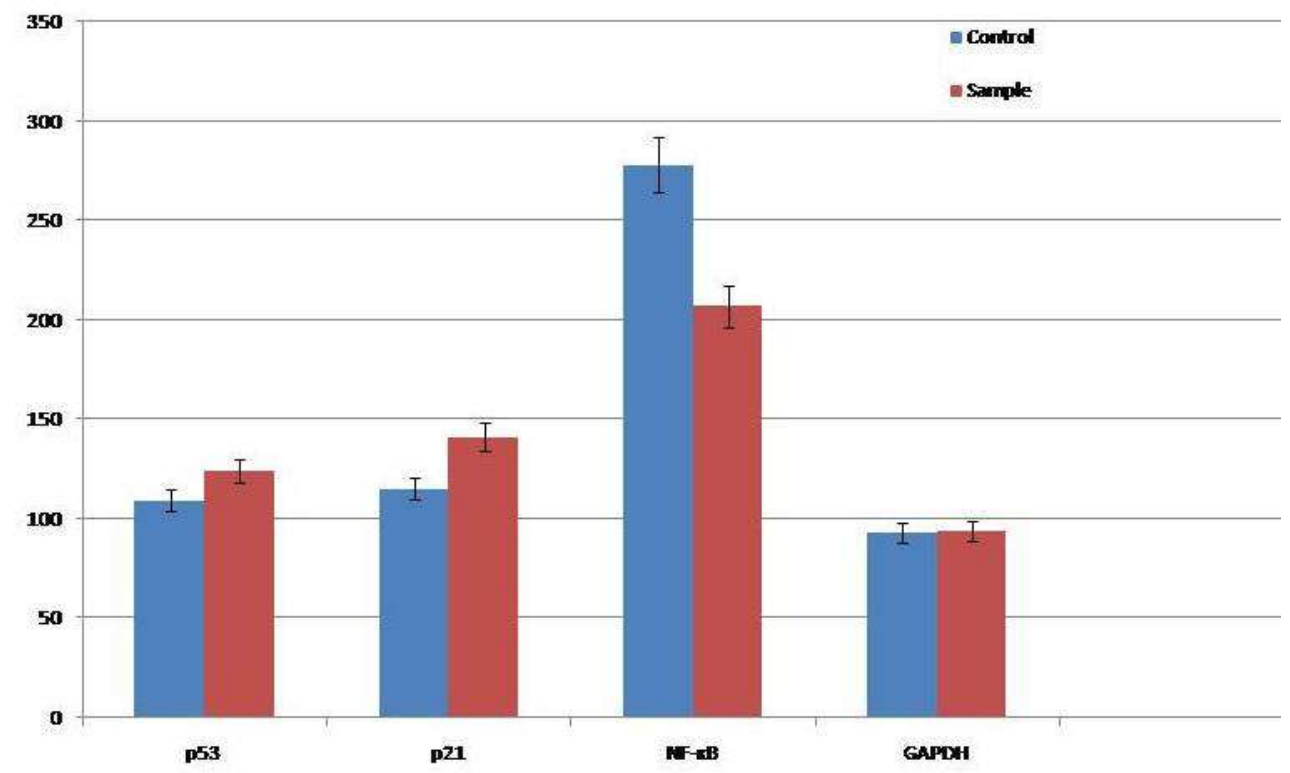

Figure 4 B:-Graphical Representation of the Gene Expression Pattern of HepG2 cells

\section{Reference:-}

1. Chaturvedi, P. A., Ghatak, A. A., Desai, N.S. (2012): Evaluation of Radical Scavenging Potential and Total Phenol Content in Woodfordia fruticosa from different altitudes, J. Plant Biochem. Biotechnol., 21(1): 17-22.

2. Ismael, G.F., Rosa, D.D., Mano, M.S., Awada, A. (2008): Novel cytotoxic drugs: new challenges, old solutions, Cancer Treat. Rev., 34(1): 89-91.

3. Kumar, D., Sharma, M., Sorout, A., Saroha, K. and Verma, S. (2016): Woodfordia fruticosa Kurz.: A Review on its Botany, Chemistry and Biological Activities, Journal of Pharmacognosy and Phytochemistry., 5(3): 29398.

4. Nitha, A., Prabha, S. P., Ansil, P. N., Latha, M.S. (2014): Curative effect of Woodfordia fruticosa Kurz. Flowers on N' Nitrosodiethylamine induced hepatocellular carcinoma in Rats, Int. J. Pharm. Pharm. Sci., 6(2): 150-55.

5. Padma, V.V. (2015): An Overview of Targeted Cancer Therapy, BioMedicine., 5(4): 1-6.

6. Pajaniradje, S., Mohankumar, K., Pamidimukkala, R., Subramanian, S. and Rajagopalan, R. (2014): Proliferative and Apoptotic Effects of Sesbania grandiflora leaves in human cancer cells, Biomed. Res. Int., 2014:474953.

7. Reaves, S. K., Fanzo, J. C., Arima, K., Wu, J. Y. J., Wang, Y. R. and Lei, K. Y. (2000): Expression of the p53 Tumor Suppressor Gene Is Up-Regulated by Depletion of Intracellular Zinc in HepG2 Cells, J. Nutr., 130(7): 1688-94.

8. Ribble, D., Goldstein, N. B., Norris, D. A. And Shellman, Y. G. (2005): A simple technique for quantifying apoptosis in 96-well plates, BMC Biotechnology., 5: 12.

9. Said, H.M., Polat, B., Hagemann, C., Anacker, J., Flentje, M. and Vodermark, D. (2009): Absence of GAPDH regulation in tumor-cells of different origin under hypoxic conditions in-vitro, BMC Research Notes., 2:8.

10. Sasidharan, S., Chen, Y., Saravanan, D., Sundaram, K. M., YogaLatha, L. (2011): Extraction, Isolation and Characterization of Bioactive Compounds from Plants' Extracts, Afr. J. Tradit. Complement Altern. Med., 8(1): $1-10$.

11. Sharma, V. (2011): Flowers of Woodfordia fruticosa exhibit cytotoxicity against Hep-2 and SK-N-MC Cancer cells, Biotechnol. Bioinf. Bioeng., 1(2): 229-33.

12. Su, M., Yu, T., Zhang, H., Wu, Y., Wang, X. and Li., G. (2016): The Antiapoptosis Effect of Glycyrrhizate on HepG2 Cells Induced by Hydrogen Peroxide, Oxid. Med. Cell Longev., 2016: 6849758.

13. Suganya, R. and Thangaraj, M. (2014): Isolation and Characterization of Leaf Extract of Derris trifoliate, Int. J. ChemTech Res., 6(9): 4115-122. 
14. Syed, Y. H., Khan, M., Bhuvaneshwari, J. and Ansari, J. A. (2013): Phytochemical Investigation and standardization of extracts of flowers of Woodfordia fruticosa; a preliminary study, J. Pharm. Biol. Sci., 4: 134140.

15. Thakkar, K. N., Prasad, A. K., Nayak, J., Iyer, S. V. And Kumar, S. (2014): Antioxidant and in vitro cytotoxic activity of extracts of aerial parts of Cocculus hirsutus(L) using cell line cultures (breast cell line), The Journal of Phytopharmacology., 3(6): 395-399.

16. Wilkening, S., Stahl, F. and Bader, A. (2003): Comparison of Primary Hepatocytes and Hepatoma Cell Line HepG2 with regard to their Biotransformation Properties, Drug Metabolism and Disposition., 31(8): 1035-42.

17. Wong, R. S. Y. (2011): Apoptosis in Cancer: From Pathogenesis to Treatment, Journal of Experimental and Clinical Cancer Research., 30: 87. 